\title{
Evaluation of Techniques for Determination of Hydroxyl Value in Materials for Different Industrial Applications
}

Laís Lopes Jesus ${ }^{1}$, Lídia Mattos Silva Murakami ${ }^{1}$ Talita de Souza Dias Mello", Milton Faria Diniz², Leandro Mattos Silva ${ }^{3}$, Elizabeth da Costa Mattos², Rita de Cássia Lazzarini Dutra1,*

Jesus LL (10) https://orcid.org/0000-0002-1349-5941

Murakami LMS (iD https://orcid.org/0000-0003-2589-7769

Mello TSD (D) https://orcid.org/0000-0002-1167-4380

Diniz MF (iD https://orcid.org/0000-0003-0246-0660

Silva LM (i) https://orcid.org/0000-0001-9180-1089

Mattos EC (iD https://orcid.org/0000-0002-9394-4910

Dutra RCL (i) https://orcid.org/0000-0001-9958-1279
How to cite

Jesus LL; Murakami LMS; Mello TSD; Diniz MF; Silva LM; Mattos EC; Dutra RCL (2019) Evaluation of Techniques for Determination of Hydroxyl Value in Materials for Different Industrial Applications. J Aerosp Technol Manag, 11: e2019. https://doi.org/10.5028/jatm.v11.1027

\begin{abstract}
When some materials need to be characterized, the hydroxyl number $(\mathrm{IOH})$ determination is especially useful, mainly for those applied in the aerospace field. Usually, this characterization is performed by wet chemistry, using methodologies involving several steps, such as derivatization. This is a time-consuming and costly step. On the other hand, when the analysis is performed by Fourier transform infrared (FT-IR) spectroscopy, the most used region is the medium infrared (MIR) and transmission techniques are usually employed. However, FT-IR methodology developed error is usually not discussed. FT-IR methodology was developed in near infrared (NIR) and MIR regions, including non-conventional techniques, such as universal attenuated total reflection (UATR) and transflectance (near infrared reflection accessory [NIRA]), and transmission, to determine $\mathrm{IOH}$ in surfactants, used in aerospace catalysts/cosmetic products, and polyesters, applied in paints. According to the samples' characteristics, surfactants were analyzed by transmission/solution and, as received, by NIRA. Polyesters were analyzed by UATR and NIRA, as received. The IOH values for all samples were also measured by wet chemistry and/or potentiometry (supplier's data) and used as reference. Good linear correlations were observed between 0.939 and 0.976 , being considered with good precision, and between $88 \%$ (NIRA) and 98\% (MIR) of the results were explained by developed methodologies.
\end{abstract}

KEYWORDS: FT-IR, Hydroxyl number, Polyesters, Surfactants, UATR

\section{INTRODUCTION}

In general, the evaluation of hydroxyl number $(\mathrm{IOH})$ in materials is carried out by conventional wet chemistry methodologies; although shown in most cases, its good accuracy is delayed and expensive due to derivatization/titrations and different reagents purchase requirements (Chalasani et al. 2013; Takahashi et al. 1996).

1.Departamento de Ciência e Tecnologia Aeroespacial - Instituto Tecnológico de Aeronáutica - Divisão de Ciências Fundamentais - São José dos Campos/SP - Brazil. 2.Departamento de Ciência e Tecnologia Aeroespacial - Instituto de Aeronáutica e Espaço - Divisão de Propulsão - São José dos Campos/SP - Brazil.

3.Brasken SA - Olefins - Production - São Paulo/SP - Brazil.

*Correspondence author: ritacld@ita.br

Received: Mar. 26, 2018 | Accepted: Jul. 04, 2018

Section Editor: Cristina Andrade 
Although this kind of determination by instrumental techniques, such as Fourier transform infrared (FT-IR) spectroscopy, is faster, especially when it does not use derivatization, it is generally performed in the most known region, the medium infrared (MIR) (Tavassoli-Kafrani et al. 2014; Takahashi et al. 1996).

In the propellants area, for instance, the $\mathrm{IOH}$ value is required in stoichiometric calculations for polyurethanes (PU) production (Pedreira et al. 2016). It is known that in such polymers production, the hydroxyl groups (OH) of polyol react with monomeric molecules containing two or more groups of isocyanates $(\mathrm{N}=\mathrm{C}=\mathrm{O})$ for crosslinks formation. Thus, IOH determination is paramount to PU products properties since they are dependent on the $\mathrm{OH}$ groups number used in polyol (Tavassoli-Kafrani et al. 2014; Pant and Patil 2016).

$\mathrm{IOH}$ values are also determined in other materials types, such as surfactants, which can be found as natural or synthetic substances and have a lipophilic (or hydrophobic) and a hydrophilic part in their chemical structure; these are responsible for surfactant molecules adsorption in the different liquid-liquid, liquid-gas, or solid-liquid interfaces of a specific system. They are considered as one of the most versatile chemicals, being applied in different industrial processes (Rossi et al. 2006).

The IOH value is used as a parameter for surfactant ethoxylation degrees. The lower the IOH, the higher the sample ethoxylation (Daltin 2011). Thus, it is understood that IOH determination will effectively contribute to the quality control of these materials by fast and precise methodologies and to the consequent evaluation of their potential in different applications.

Surfactants are applied in cosmetic and drug areas, and IOH determination is essential for these compounds to meet certain quality control bands in specific purposes, as it should be in any product application, evidently aiming for market survival (Kazuaki et al. 2014).

In the catalyst area for propellants, surfactants were applied as a microemulsion method component to obtain iron oxide, resulting in products with particles, narrow range, and high surface area, among others (Campos et al. 2015a; Campos et al. 2015b). As it is known, microemulsions are defined as thermodynamically stable, isotropic, and transparent systems, being formed mostly by an oil phase, composed of aliphatic or aromatic hydrocarbons, and an aqueous phase, stabilized by a surfactant and a cosurfactant (Rossi et al. 2007).

Among other data, the iron oxide's catalytic effect obtained by microemulsion synthesis on the decomposition of ammonium perchlorate (AP) by simultaneous thermal analysis means (thermogravimetric analysis/differential thermal analysis [TG/DTA]) was evaluated in the Campos et al. $(2015 \mathrm{a}, \mathrm{b})$ study. It was observed that iron oxide, encoded by F1, one of the synthesized samples, which contained in its composition the surfactant called Triton X-100, that contains polyethylene glycol as a hydrophilic part and an aromatic as a hydrophobic part, presented high surface area $\left(388 \mathrm{~m}^{2} \mathrm{~g}^{-1}\right)$ and significantly affected the activation kinetic parameter of AP thermal reaction, especially in the high decomposition temperature region.

There are also references about the surfactants use in carbon nanotubes (CNT) (graphene sheets coiled to form a cylindrical piece with a diameter close to $1 \mathrm{~nm}$ ) in the literature (Silva et al. 2013; Botelho et al. 2011; Vaisman et al. 2006). According to Silva et al (2013), CNT have excellent properties, such as mechanical, electrical, magnetic, and thermal, but generally they are in highly homogeneous dispersion. However, they have low solubility in solvents. One way to make it work is to use surfactants.

Tween surfactants, which are also characterized in this current paper and are polysorbate molecules containing polyethylene glycol (hydrophilic part) and fatty acid ester (hydrophobic part) are quoted by Shen et al. (2011), among other surfactants, such as lauryl sulphates, for this application. The employment of polyethylene glycol surfactants in the aerospace area motivated the use of this type of non-ionic surfactant in this current study.

Alisson (2017) has reported a study that allows the CNT use in aerospace structures as alternative materials to metals and metal alloys currently applied in this sector to minimize the damages caused by some possible particles in satellites and spaceships. The study has the goal of developing a process to make these materials more resistant, but there are still difficulties related to cost, among others. However, there is scope for further research. Recently, Vargas et al. (2017) studied composites containing graphene oxide and polyaniline, obtaining a product with good properties, aimed at aerospace application, and used, among other techniques, infrared (IR) spectroscopy to evaluate the interaction between the products used. 
Polyester is another hydroxylated material, one of the most versatile copolymers. It is widely applied in things such as fibers, plastics, composites, and coatings. Polyesters are macromolecules that have carboxylate groups in the main chain, through acid components and alcohol reactions (Dholakiya, 2012), which makes the determination of IOH a great deal, balancing the reaction, aiming at the production of these materials.

Polyesters can be used in several applications, such as the printing ink industry for packaging/adhesives, in PU production. The final product is dependent on the $\mathrm{OH}$ or isocyanate $(\mathrm{NCO})$ amount remaining, interfering in adhesion. If $\mathrm{OH}$ is in excess and unreacted, it may interfere with adhesion and prevent polymer drying (tack). It is more difficult to have NCO unreacted, since it is very reactive, but for this reason it can also produce undesirable compounds.

Regarding the polyester application diversity, the determination of IOH for the final product quality plays a major role and the methodology applied for this measurement was wet chemistry (ASTM E222-17); it was also used to study this material type in this current paper, by FT-IR spectroscopy.

As mentioned before, the determination of a functional group, such as hydroxyl and NCO, is generally performed by FT-IR techniques in MIR region and it is imperative in the aerospace field. Studies of compounds or polymers by near infrared (NIR) region appear in small number. However, quantitative analyses in this region are generally more accurate than in the MIR region. NCO in PU adhesives (Siqueira et al. 2008) and PU resin in nitrocellulose (NC) binder mixtures used in paints/coatings determinations (Rodrigues et al. 2014) are good examples to be quoted.

One technique with great potential in the NIR region is the transmission and near infrared reflection analysis (NIRA). For solid state, the analysis is done by reflectance, such as the diffuse technique, and by transflectance for liquid state (Stark et al. 1986). Roy and Kradjel (1988) determined IOH by NIRA through band at $4878 \mathrm{~cm}^{-1}$ measured in duplicate with the error variation presented between 0.06 and 2.20. However, the band used is a combination band, which involves more than one functional group. In addition, this kind of analysis should be done at least in triplicate to improve accuracy.

All things considered, some attention points can be mentioned for future references: a) the IOH determination is usually done by wet chemistry, consuming long analysis time, which is not suitable for quality control processes; b) there are fewer quantitative than qualitative FT-IR publications; c) determinations are performed using conventional transmission mode to obtain FT-IR spectra; d) FT-IR spectroscopy specific relative and methodology errors (Hórak and Vítek 1978) are not found in most publications, there are only references of standard deviations, but comparing with traditional methods (TavassoliKafrani et al. 2014); e) and there are few publications using reflection techniques for functional groups determination, both in the MIR and the NIR region. However, there are faster non-conventional reflection techniques that can be applied with a small amount of samples, such as universal attenuated total reflection (UATR) or NIRA (Stark et al. 1986), and these are less exploited.

Examples of functional groups quantitative analyses using UATR or NIRA have been mentioned: Damazio et al. (2014) analyzed the ethylene propylene diene monomer (EPDM) rubber, used in aerospace thermal insulations, with UATR, showing that this reflection technique is suitable and precise. Mello et al. (2018) used UATR and NIRA for MIR data validation for ester plasticizer determination in NC, used for industrial and military purposes, with good results.

Given all these facts, it is proposed in this current study the development of FT-IR-MIR/NIR methodologies for IOH determination in surfactants, based in polyethylene glycol, and in polyesters, used in printing inks, using methods of obtaining FT-IR transmission/UATR (MIR) and transflectance (NIRA) spectra; it is also proposed a wide discussion in terms of time and determination of accuracy.

\section{MATERIALS AND METHODS SURFACTANTS}

For FT-IR methodology development, aiming at IOH determination in surfactants, seven samples of these compounds were kindly provided by suppliers, and their characteristics are described in Table 1. 
Table 1. Composition and structural characteristics of surfactants and $\mathrm{IOH}$ values.

\begin{tabular}{|c|c|c|c|c|}
\hline \multirow{2}{*}{$\begin{array}{l}\text { Commercial } \\
\text { name }\end{array}$} & \multirow{2}{*}{$\begin{array}{c}\text { Structural } \\
\text { characteristic }\end{array}$} & \multicolumn{2}{|c|}{$\begin{array}{c}\text { IOH [potentiometry] } \\
\text { [mg KOH/g] [Basf, 2007] }\end{array}$} & \multirow{2}{*}{$\begin{array}{c}\text { IOH (wet chemistry } \\
\text { method, acetylation] } \\
\text { [mg KOH/g] (ASTM E222-17) }\end{array}$} \\
\hline & & Range & $\begin{array}{c}\text { Value } \\
\text { measured }\end{array}$ & \\
\hline Alkonat L 230 & Poly (ethylene glycol) of lauryl alcohol & $39-48$ & 42.7 & 46.4 \\
\hline Eumulgin B2 & Poly (ethylene glycol) & $49-55$ & 52.1 & 51.0 \\
\hline Alkonat CE 200F & Poly (ethylene glycol) & $50-58$ & 53.8 & 53.1 \\
\hline Eumulgin SMO 20 & Sorbitan poly (oxyethylene) (20) monolaurate & $65-80$ & 72.5 & 65.3 \\
\hline Eumulgin SML 20 & Sorbitan poly (oxyethylene) (20) monolaurate & $96-108$ & 105.0 & 102.9 \\
\hline Tween 20 & Sorbitan poly (oxyethylene) (20) monolaurate & $96-106$ & 102.0 & 104.0 \\
\hline Eumulgade A6 & Poly (ethylene glycol) & $115-134$ & 130.0 & 126.8 \\
\hline
\end{tabular}

\section{POLYESTERS}

For FT-IR methodology development, aiming at IOH determination in polyesters, seven samples of these compounds were kindly provided by Nitro Química, and their characteristics are described in Table 2.

Table 2. Composition and structural characteristics of polyesters and $\mathrm{IOH}$ values.

\begin{tabular}{|c|c|c|c|}
\hline \multirow{2}{*}{ Commercial name } & \multirow{2}{*}{$\begin{array}{c}\text { Structural } \\
\text { characteristic }\end{array}$} & \multicolumn{2}{|c|}{ IOH (value) [mg KOH/g]) (ASTM E222-17) } \\
\hline & & Range & Value measured \\
\hline BASE 001 & \multirow{7}{*}{$\begin{array}{c}\text { Polyesters } \\
\text { (based on phthalic acids } \\
\text { and glycols) }\end{array}$} & $29-39$ & 36.59 \\
\hline BASE 009 & & $76-84$ & 82.47 \\
\hline BASE 008 & & $85-90$ & 90.00 \\
\hline BASE 003 & & $128-140$ & 137.91 \\
\hline BASE 807 & & $160-180$ & 172.49 \\
\hline BASE 002 & & 215-225 & 223.05 \\
\hline BASE 005 & & $300-330$ & - \\
\hline
\end{tabular}

\section{FT-MIR AND NIRA METHODOLOGIES}

NIR and MIR regions were used for methodologies' development, aiming at $\mathrm{OH}$ quantification in surfactant samples containing polyethylene glycol and polyesters samples using standard and/or non-conventional techniques, such as NIRA and UATR.

The PerkinElmer FT-IR Spectrum One spectrometer was used under the following conditions: MIR (4000 to $\left.400 \mathrm{~cm}^{-1}\right)$ and NIR (10000 to $4000 \mathrm{~cm}^{-1}$ ) regions, 20 scans, and $4 \mathrm{~cm}^{-1}$ resolution. The surfactant samples, with IOH known, were measured in triplicate, by wet chemistry method (acetylation), United States Pharmacopeia-National Formulary (USP-NF), and analyzed in MIR region - by transmission, as liquid films, in $\mathrm{CCl}_{4}$ solution, in cesium iodide (CsI) closed cell, with spacer $0.050 \mathrm{~mm}$ - and in NIR region, using the NIRA transflectance accessory, as received. The polyester samples were analyzed using the same spectrometer and the same conditions, but by UATR in MIR region and by NIRA, as received, with known IOH, measured by wet chemistry (acetylation) (ASTM E222-17).

The analytical band $\mathrm{A}_{3500}$ (stretching $-\mathbf{v} \mathrm{OH}$ ) was selected for IOH determination in surfactants using MIR methodology with baseline from 3710 to $3100 \mathrm{~cm}^{-1}$. MIR and NIRA calibration curves were developed, respectively, relating the $\mathrm{A}_{3500}$ and $\mathrm{A}_{7000}$ bands to the $\mathrm{IOH}$ of each surfactant sample. The band at $7000 \mathrm{~cm}^{-1}$ is probably assigned to the first overtone of $\mathrm{A}_{3500}$ band stretching (Walling and Dabney 1986; Roy and Kradjel 1988). The baseline for NIRA methodology comprised the 7474 to the $6200 \mathrm{~cm}^{-1}$ regions. MIR and NIRA data calibration curves represent the median (Hórak and Vítek 1978) of five bands with $\mathrm{A}_{3500}$ and $\mathrm{A}_{7000}$ intensity values, respectively. 
The analytical bands $\mathrm{A}_{3500}$ and $\mathrm{A}_{7000}$ were also selected for IOH determination in polyesters using MIR and NIRA methodologies, with baselines from 3660 to $3100 \mathrm{~cm}^{-1}$ and 7475 to $6550 \mathrm{~cm}^{-1}$, respectively. MIR and NIRA calibration curves were developed, relating the band $\mathrm{A}_{3500}$ and $\mathrm{A}_{7000}$, respectively, to the IOH of each polyester sample. MIR and NIRA data calibration curves represent the median ( $\mu$ or X) (Hórak and Vítek 1978; Mello et al. 2018) of five values (Takahashi et al. 1996; Damazio 2015) of $A_{3500}$ and $\mathrm{A}_{7000}$ bands' intensity, respectively.

Standard deviation calculation (Hórak and Vítek 1978) (Eq. 1 and Eq. 2), relative error (Eq. 3), and methodology errors (median of relative errors) developed for both surfactants and polyesters were performed using non-parametric statistical treatment and also quantitative data (median absorbance values) obtained by FT-IR spectroscopy (Hórak and Vítek 1978), already used successfully in previous and recent studies of this group (Mello 2017; Damazio 2015). These deviations were also compared to those obtained by means of a wet chemistry method for the $\mathrm{IOH}$ determination of surfactant samples.

$$
\hat{\sigma}_{\widehat{\mu}}=\hat{\sigma} / \sqrt{n}
$$

where $\hat{\sigma}_{\hat{\mu}}$ is standard deviation and $\hat{\sigma}$ is the standard deviation and $\sqrt{n}$ is the number of measurements per sample.

The standard deviation for the measurements' number performed is given by Eq. 2 .

$$
\hat{\sigma}=K_{R} \cdot R
$$

where $R$ is the difference between the highest and the lowest absorbance value and $\mathrm{K}_{\mathrm{R}}$ is the coefficient to calculate the standard deviation of a values range (for five experiments, $K_{R}=0.430$ ) (Hórak and Vítek 1978).

Relative error or relative deviation (RD) (\%):

$$
(R D)=\left(\hat{\sigma}_{\widehat{\mu} / \mu}\right) \times 100
$$

where RD is relative error, $\hat{\sigma}_{\hat{\mu}}$ is standard deviation, and $\mu$ is median value.

The methodology error was considered as the median of relative errors, as in previous studies (Mello 2017; Damazio 2015; Dutra 1997; Dutra e Soares 1998).

\section{RESULTS AND DISCUSSIONS SURFACTANTS}

The FT-IR IOH determination in surfactants was performed in MIR (transmission) and NIRA (transflectance) regions, with the IOH reference values measured by wet chemistry or potentiometry. The errors (mean standard deviation, relative and FT-IR methodologies, and wet chemistry method) were measured, and a comparison with the wet chemistry data was performed based on these FT-IR errors and analysis time.

\section{IOH determination in surfactants by FT-MIR (transmission)}

In Fig. 1, the FT-IR/MIR spectra of surfactant samples used for IOH determination are shown. It can be observed that there is an increase in $\mathrm{OH}$ band intensity, around $3500 \mathrm{~cm}^{-1}$, according to IOH increase, obeying Lambert-Beer's law (Smith 1979).

Table 3 includes data on the FT-MIR (transmission) developed methodology and potentiometry or wet chemistry method (reference). In Fig. 2, the $\mathrm{A}_{3500}$ values are plotted against the relative surfactant $\mathrm{IOH}$ samples measured by potentiometry (supplier's data). In Fig. 3, the values of $\mathrm{A}_{3500}$ as a function of $\mathrm{IOH}$ relative to those measured by wet chemistry (acetylation) are shown. 


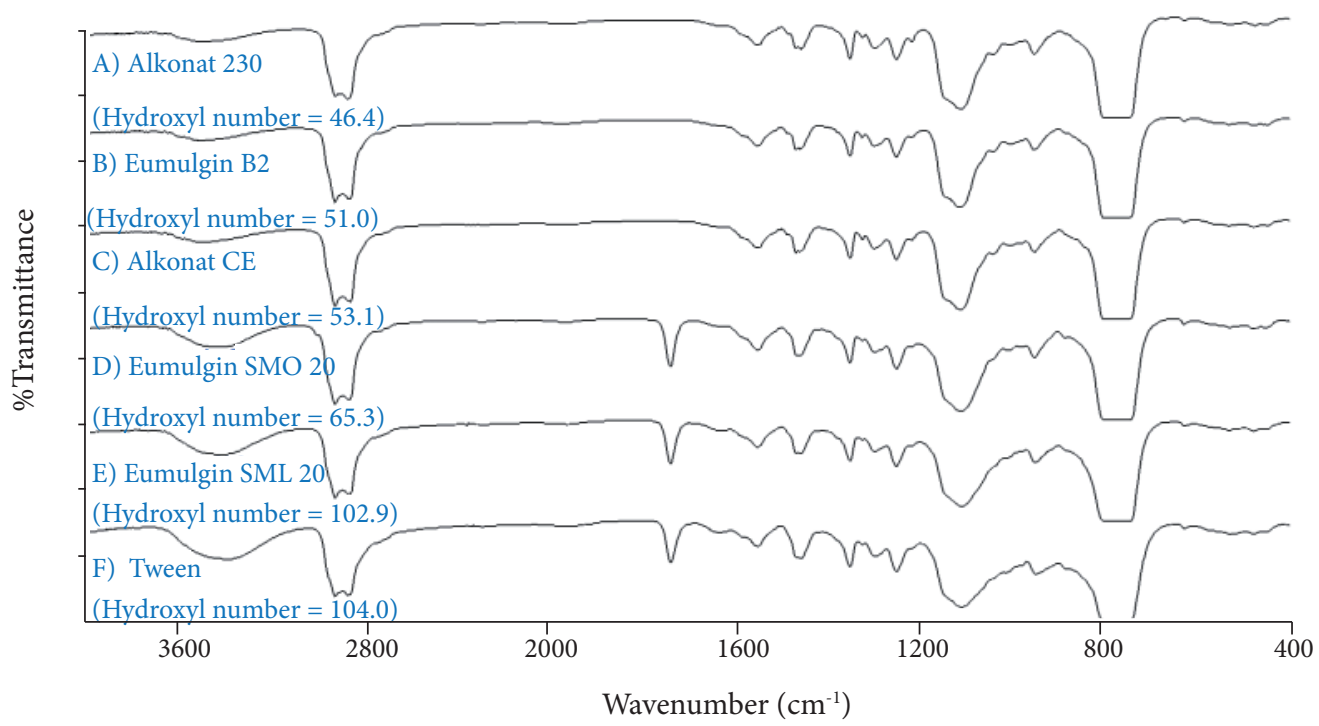

Figure 1. Fourier transform medium infrared transmission spectra of surfactant samples (Hydroxyl number in $\mathrm{mg} \mathrm{KOH} / \mathrm{g}$, measured by wet chemistry method, acetylation) prepared as solution in sealed Cesium iodide cell of $0.050 \mathrm{~mm}-1 \mathrm{~g}$ in $10 \mathrm{~mL}$ of CCl${ }_{4}$.

Table 3. Methodologies data, FT-MIR (transmission), potentiometry, and wet chemistry for IOH determination in surfactants.

\begin{tabular}{|c|c|c|c|c|c|c|c|c|}
\hline \multirow{3}{*}{ Sample } & \multicolumn{3}{|c|}{ FT-MIR [transmission] } & \multirow{2}{*}{\multicolumn{2}{|c|}{$\begin{array}{c}\mathrm{IOH} \\
\text { potentiometry } \\
\text { [mg KOH.g] }\end{array}$}} & \multicolumn{3}{|c|}{ IOH [Wet chemistry method] } \\
\hline & \multirow{2}{*}{$\begin{array}{c}\mathbf{A}_{3500} \\
\text { [median value) }\end{array}$} & \multirow{2}{*}{$\begin{array}{c}\text { Standard } \\
\text { deviation } \\
{\left[\hat{\sigma}_{\mu}\right]}\end{array}$} & \multirow{2}{*}{$\begin{array}{c}\text { Relative } \\
\text { error } \\
\text { [\%] }\end{array}$} & & & \multirow{2}{*}{$\begin{array}{l}\text { Mean value } \\
\text { [mg } \mathrm{KOH} / \mathrm{g}]\end{array}$} & \multirow{2}{*}{$\begin{array}{l}\text { Variation } \\
\text { from the } \\
\text { mean }\end{array}$} & \multirow{2}{*}{$\begin{array}{c}\text { Relative error } \\
\text { [ref. value suplier] } \\
\text { [\%] }\end{array}$} \\
\hline & & & & Range & Value & & & \\
\hline Alkonat 230 & 0.056 & 0.003 & 5.4 & $39-48$ & 42.7 & 46.4 & 6.5 & 8.6 \\
\hline Eumulgin B2 & 0.055 & 0.001 & 1.8 & $49-55$ & 52.1 & 51.0 & 10.4 & 2.1 \\
\hline Alkonat CE & 0.060 & 0.002 & 3.3 & $50-58$ & 53.8 & 53.1 & 12.8 & 1.3 \\
\hline Eumulgin SMO 20 & 0.097 & 0.004 & 4.1 & $65-80$ & 72.5 & 65.3 & 0.8 & 9.9 \\
\hline Tween & 0.130 & 0.003 & 2.3 & $96-106$ & 102.0 & 104.0 & 9.4 & 2.0 \\
\hline Eumulgin SML 20 & 0.138 & 0.004 & 2.9 & $96-108$ & 105.0 & 102.9 & 10.1 & 2.0 \\
\hline Methodology error & & 2.9 & & - & - & - & 9.4 & 2.1 \\
\hline
\end{tabular}

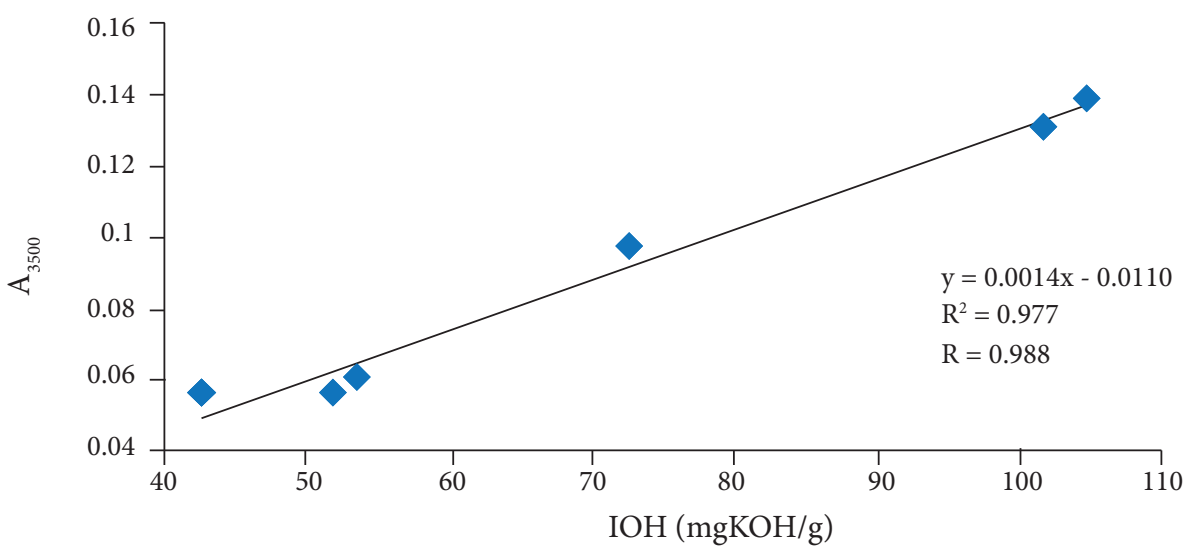

Figure 2. FT-MIR calibration curve (transmission, surfactant solution in $\mathrm{CCl}_{4}$ ], $\mathrm{A}_{3500}$ versus $\mathrm{IOH}$ (measured by potentiometry, supplier's data). 


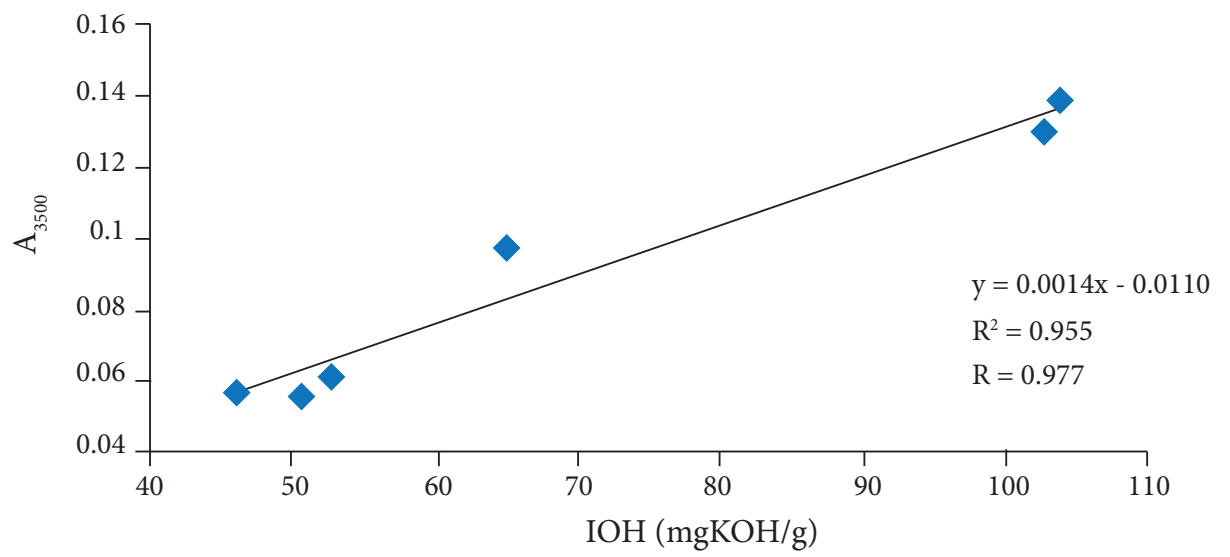

Figure 3. FT-MIR calibration curve (transmission, surfactant solution in $\mathrm{CCl}_{4}$ ), $\mathrm{A}_{3500}$ versus $\mathrm{IOH}$ (measured by wet chemistry method, acetylation).

Good linear correlations were observed, $\mathrm{R}=0.988$ and $\mathrm{R}=0.977$, respectively, for the calibration or analytical curves (Eq. 4 and Eq. 5). Respectively, the determination coefficients $\mathrm{R}^{2}$ (Pimentel 1996) were 0.976 and 0.955 . Therefore, between 0.95 and $0.98 \%$ of the values were explained by the methodology.

$$
\mathrm{y}=0.0014 \mathrm{x}-0.011
$$

where $y$ is the median value of $\mathrm{A}_{3500}$ and $\mathrm{x}$ is the $\mathrm{IOH}$ value $(\mathrm{mg} \mathrm{KOH} / \mathrm{g})$.

$$
\mathrm{y}=0.0014 \mathrm{x}-0.010
$$

where $y$ is the median value of $\mathrm{A}_{3500}$ and $\mathrm{x}$ is the $\mathrm{IOH}$ value $(\mathrm{mg} \mathrm{KOH} / \mathrm{g}$ ).

Evaluating the data in Table 3, it can be observed that the variation between measurements in FT-IR methodology (2.9\%) (Hórak and Vítek 1978) is lower than the one obtained by wet chemistry method (9.4\%) (Baccan et al. 2001). The greater variation in values in the wet chemistry method may be due to the greater number of steps, also impacting the analysis time (4 hours), in comparison to FT-IR methodology (1 hour). Regarding the reference, measured by potentiometry, the wet chemistry method presents a smaller error $(2.1 \%)$.

The FT-IR methodology error, around 3\%, is acceptable in relation to the FT-IR spectrophotometer accuracy limit ( $\leq 2 \%)$ (Hórak and Vítek 1978), which is usually obtained in ideal conditions, where the analytical band is thinner or more intense than these $\mathrm{OH}$ group materials, which is wider because of the hydrogen bonding interaction possibility (Smith 1979).

The curves in Fig. $4(\mathrm{R}=0.991)$ and Fig. $5(\mathrm{R}=0.998)$ show the relationship between the IOH values supplied and measured, both by wet chemistry and FT-IR, for the surfactants studied. The data measured by FT-IR show slightly better linearity, relative to the reference data (from supplier) (0.988, FT-IR, and 0.986, wet chemistry).

\section{$10 \mathrm{H}$ determination in surfactants by FT-NIRA}

Figure 6 shows FT-IR/NIRA spectra used for IOH determination in surfactant samples. There is basically an increase in $\mathrm{OH}$ band intensity, around $7000 \mathrm{~cm}^{-1}$, according to the $\mathrm{IOH}$ increase, obeying Lambert-Beer's law (Smith 1979).

Since the samples, prepared as a solution, as it had been done in the MIR region, did not respond adequately to the NIRA analysis, an attempt was made to analyze them directly, without solvent use or a complex step of material's preparation. This feature was not a simple task, because, in some cases, it was necessary to form a film for the most adequate preparation of the sample. Thus, it was decided to analyze only four samples, representing the levels: lower, intermediate (two samples), and high.

The data used for calibration curve development are shown in Table 4, Fig. 7, and Fig. 8. The methodology presented, in the possible analysis' conditions, a linear correlation that was considered good, in relation to the supplier's data by potentiometry, $\mathrm{R}=0.945$ and $\mathrm{R}^{2}=0.892$; and in relation to wet chemistry method data (acetylation), $\mathrm{R}=0.939$ and $\mathrm{R}^{2}=0.882, \mathrm{for} \mathrm{IOH}$ 


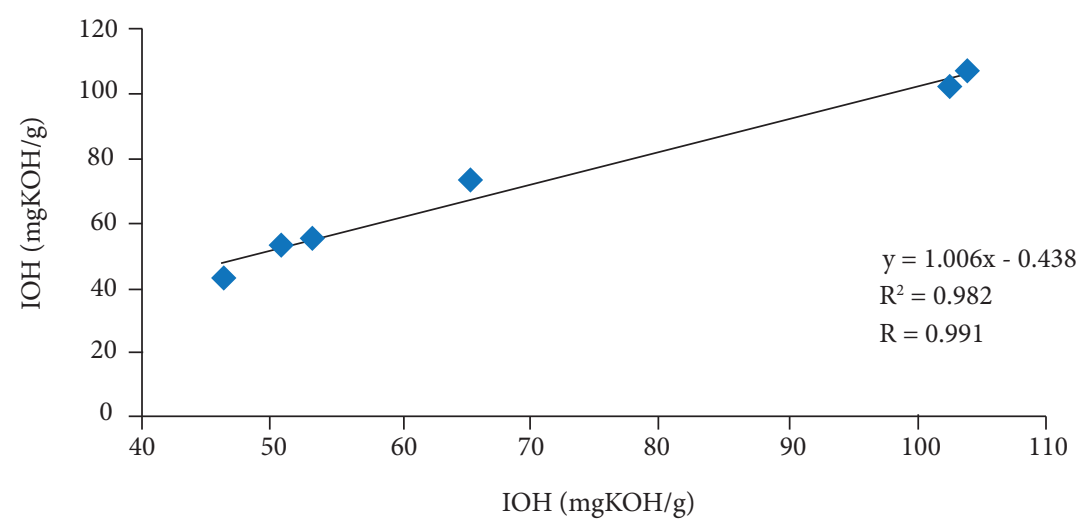

Figure 4. $\mathrm{IOH}$ (from supplier, by potentiometry) versus $\mathrm{IOH}$ by wet chemistry method (acetylation), for the surfactants studied.

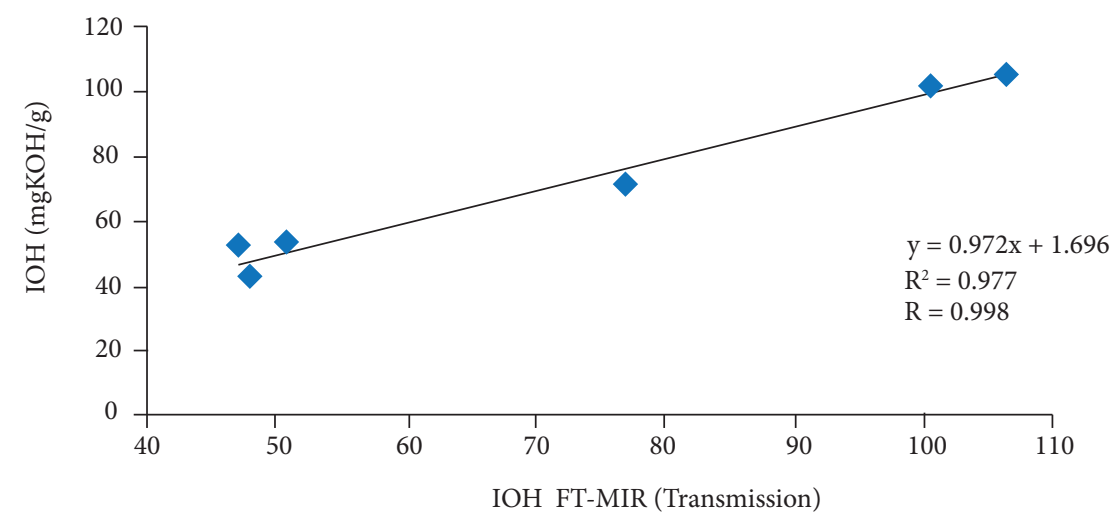

Figure 5. $\mathrm{IOH}$ (from supplier, by potentiometry) versus $\mathrm{IOH}$ measured by FT-MIR (transmission), for the surfactants studied.

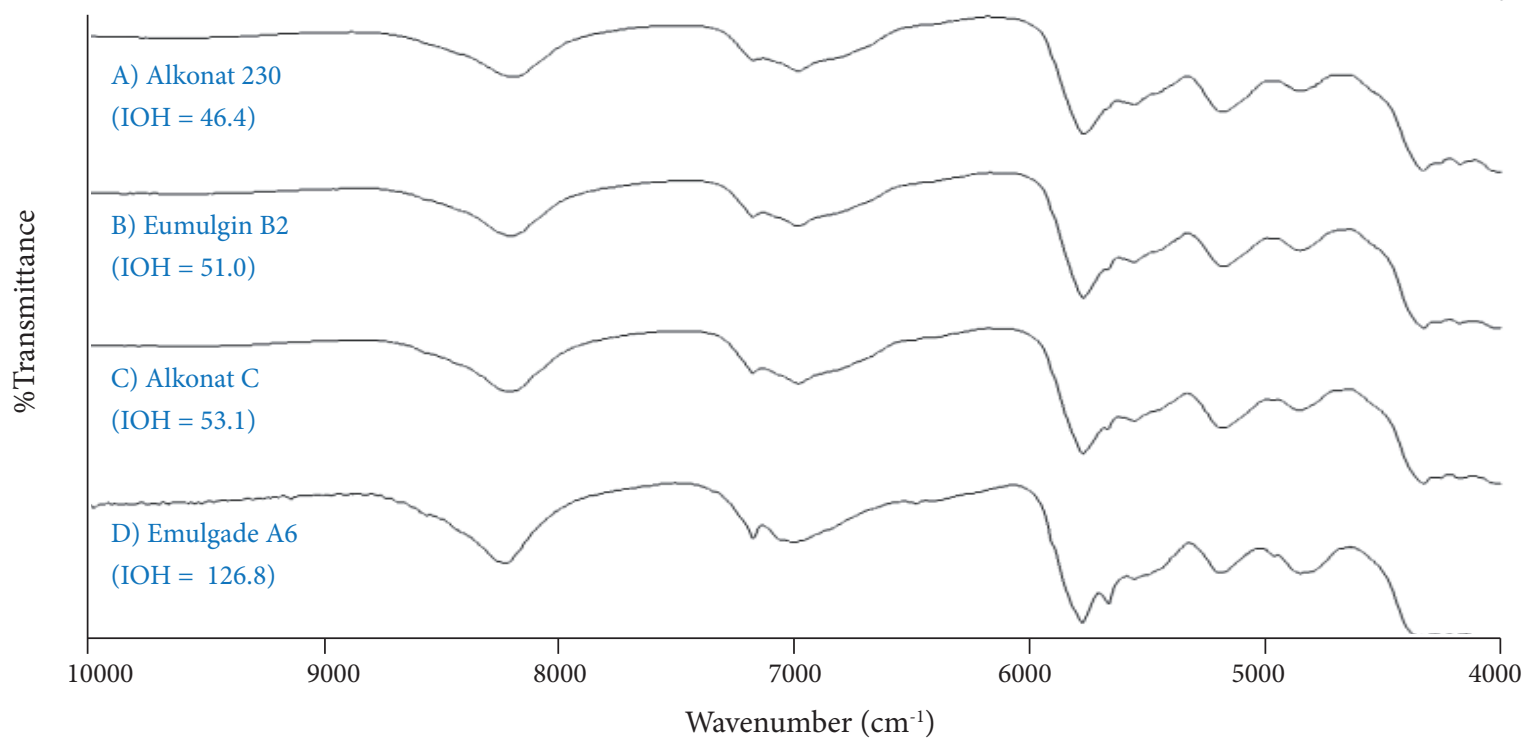

Figure 6. FT-MIR reflection analysis spectra of surfactants analyzed as received $(\mathrm{IOH}$ in $\mathrm{mg} \mathrm{KOH} / \mathrm{g}$, measured by wet chemistry method, acetylation). 
Table 4. Methodologies data, FT-NIRA, potentiometry, and wet chemistry method for IOH determination in surfactants.

\begin{tabular}{|c|c|c|c|c|c|c|c|}
\hline \multirow[b]{2}{*}{ Sample } & \multicolumn{3}{|c|}{ FT-NIRA } & \multirow[b]{2}{*}{$\begin{array}{c}\text { IOH } \\
\text { from supplier } \\
\text { [potentiometry] }\end{array}$} & \multicolumn{3}{|c|}{ IOH [wet chemistry method] } \\
\hline & $\begin{array}{c}\mathbf{A}_{7000} \\
\text { [median value) }\end{array}$ & $\begin{array}{c}\text { Standard } \\
\text { deviation } \\
{[\%]}\end{array}$ & $\begin{array}{c}\text { Relative } \\
\text { error } \\
{[\%]}\end{array}$ & & $\begin{array}{l}\text { Mean value } \\
\text { [mg } \mathrm{KOH} / \mathrm{g}]\end{array}$ & $\begin{array}{l}\text { Variation from } \\
\text { the mean }\end{array}$ & $\begin{array}{c}\text { Relative } \\
\text { error } \\
\text { [\%] }\end{array}$ \\
\hline Alkonat 230 & 0.155 & 0.005 & 3.22 & 42.7 & 46.4 & 6.5 & 8.6 \\
\hline Eumulgin B2 & 0.156 & 0.010 & 6.41 & 52.1 & 51.0 & 10.4 & 2.1 \\
\hline Alkonat CE & 0.164 & 0.009 & 5.49 & 53.8 & 53.1 & 12.8 & 1.3 \\
\hline Emulgate A6 & 0.177 & 0.011 & 6.21 & 130.0 & 126.8 & 9.9 & 2.5 \\
\hline Methodology error & & 5.85 & & - & - & 10.2 & 2.3 \\
\hline
\end{tabular}

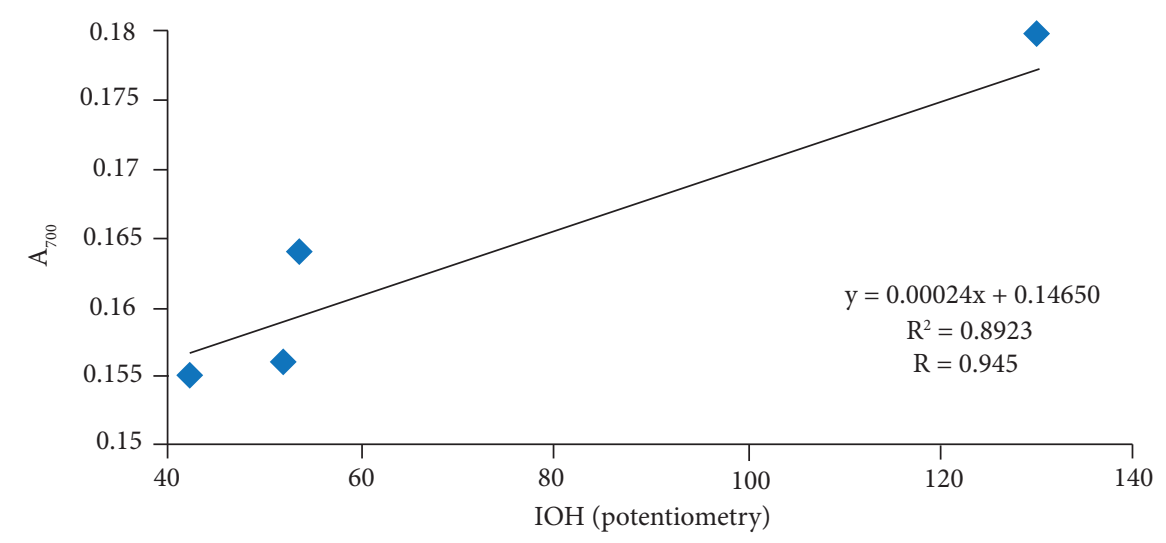

Figure 7. FT-NIRA calibration curve for $\mathrm{IOH}$ determination in surfactants $-\mathrm{A}_{7000}$ versus $\mathrm{IOH}$ (measured by potentiometry, supplier's data).

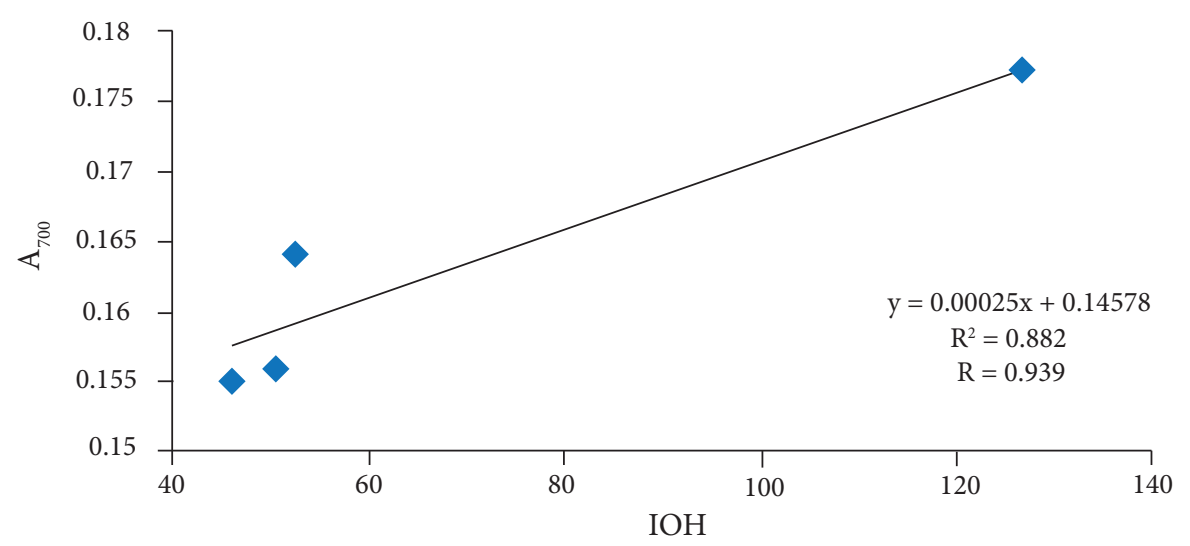

Figure 8. FT-NIRA calibration curve for $\mathrm{IOH}$ determination in surfactants $-\mathrm{A}_{7000}$ versus $\mathrm{IOH}$ (measured by wet chemistry method).

determination in surfactants, using NIRA, according to Eq. 6 (calibration curve $-\mathrm{A}_{7000} \times \mathrm{IOH}$ by potentiometry) and Eq. 7 (calibration curve $-\mathrm{A} 7000 \times \mathrm{IOH}$ by wet chemistry method):

$$
\mathrm{y}=0.00024 \mathrm{x}-0.14650
$$

where: $y$ is the median value of $\mathrm{A}_{7000}$ and $\mathrm{x}$ is the $\mathrm{IOH}$ value $(\mathrm{mg} \mathrm{KOH} / \mathrm{g})$, measured by potentiometry or wet chemistry method (acetylation). 


$$
y=0.00025 x-0.14578
$$

where: $y$ is the median value of $\mathrm{A}_{7000}$ and $\mathrm{x}$ is the $\mathrm{IOH}$ value $(\mathrm{mg} \mathrm{KOH} / \mathrm{g})$, measured by potentiometry or wet chemistry method (acetylation).

The methodology error of 5.85\% may reflect the difficulties found in the NIRA methodology, and according to samples' nature and technique's characteristics it has presented the error of $\leq 2 \%$, meeting ideal conditions (Hórak and Vítek 1978). However, studies about IOH determination by NIR (Roy and Kradjel 1988) quote errors between 2.20-4.20\%, which is also above the equipment's accuracy limit (Hórak and Vítek 1978). It should also be considered that the error $>2 \%$ can be accepted regarding to the technology applied, which is based only on a material's specification range (Mello et al. 2018).

Taking Table 4 data in consideration, it can be observed that the variation between measurements in FT-IR methodology (5.85\%) (Hórak and Vítek 1978) is lower than that obtained by wet chemistry method (10.2\%) (Baccan et al. 2001). The value variation noticed in wet chemistry method could be influenced by the number of steps, which was likely impacted by the longer analysis time (4 hours), compared to the FT-IR methodology (1 hour). Regarding the reference measured by potentiometry, the wet chemistry method presented a smaller error $(2.3 \%)$.

\section{POLYESTERS}

\section{IOH determination in polyesters by FT-MIR/UATR}

Figure 9 shows FT-MIR/UATR spectra used for IOH determination of polyester samples. It can be observed that, in the same way as for surfactants, there is an increase in $\mathrm{OH}$ band intensity, around $3500 \mathrm{~cm}^{-1}$, according to IOH increase and LambertBeer's law (Smith 1979).

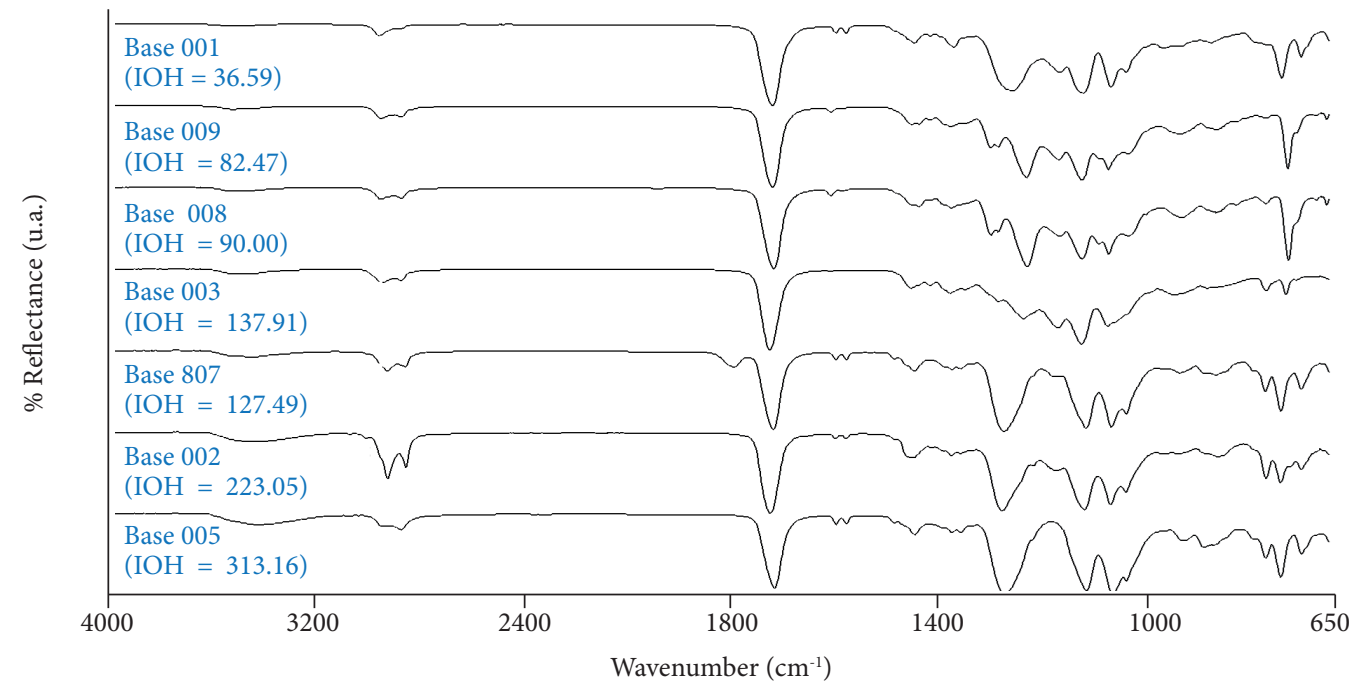

Figure 9. FT-MIR (UATR) spectra of polyester samples $(\mathrm{IOH}$ in $\mathrm{mg} \mathrm{KOH} / \mathrm{g})$ analyzed as received.

Table 5 includes data on the developed FT-MIR/UATR methodology. In Fig. 10, the $\mathrm{A}_{3500}$ values are plotted against the relative supplier's polyester samples $\mathrm{IOH}$ (reference), measured by acetylation, given in Table 5 . A good linear correlation, $\mathrm{R}=0.964$, was observed for calibration curve (Eq. 8$)$, and about $93 \%\left(R^{2}=0.9289\right)$ of the values were explained by the methodology: where: $\mathrm{y}$ is the median value of $\mathrm{A}_{3500}$ and $\mathrm{x}$ is the $\mathrm{IOH}$ value $(\mathrm{mg} \mathrm{KOH} / \mathrm{g})$.

$$
\mathrm{y}=0.00012 \mathrm{x}-0.00133
$$

Regarding the data in Table 5, it can be observed that the FT-MIR (UATR) methodology error was around 5\%, which is acceptable 
Table 5. Methodologies data and FT-MIR (UATR) for IOH determination in polyesters.

\begin{tabular}{|c|c|c|c|c|c|}
\hline \multirow{3}{*}{ Sample } & \multicolumn{3}{|c|}{ FT-MIR (UATR) } & \multirow{2}{*}{\multicolumn{2}{|c|}{$\begin{array}{c}\text { IOH [from supplier wet chemistry } \\
\text { method, acetylation] } \\
\text { [mg } \mathrm{KOH} / \mathrm{g}]\end{array}$}} \\
\hline & \multirow{2}{*}{$\begin{array}{c}A_{3500} \\
\text { (median value) }\end{array}$} & \multirow{2}{*}{$\begin{array}{l}\text { Standard deviation } \\
\qquad\left[\hat{\sigma}_{\mu}\right]\end{array}$} & \multirow{2}{*}{$\begin{array}{c}\text { Relative error } \\
\text { [\%] }\end{array}$} & & \\
\hline & & & & Range & Value measured \\
\hline BASE 001 & 0.006 & 0.000 & 0.0 & $29-39$ & 36.59 \\
\hline BASE 009 & 0.012 & 0.001 & 8.3 & $76-84$ & 82.47 \\
\hline BASE 008 & 0.014 & 0.000 & 0.0 & $85-90$ & 90.0 \\
\hline BASE 003 & 0.018 & 0.001 & 5.5 & $128-140$ & 137.91 \\
\hline BASE 807 & 0.021 & 0.001 & 4.8 & $160-180$ & 172.49 \\
\hline BASE 002 & 0.022 & 0.000 & 0.0 & $215-225$ & 223.05 \\
\hline BASE 005 & 0.043 & 0.001 & 2.3 & $300-330$ & 313.16 \\
\hline Methodology error & & 5.1 & & - & - \\
\hline
\end{tabular}

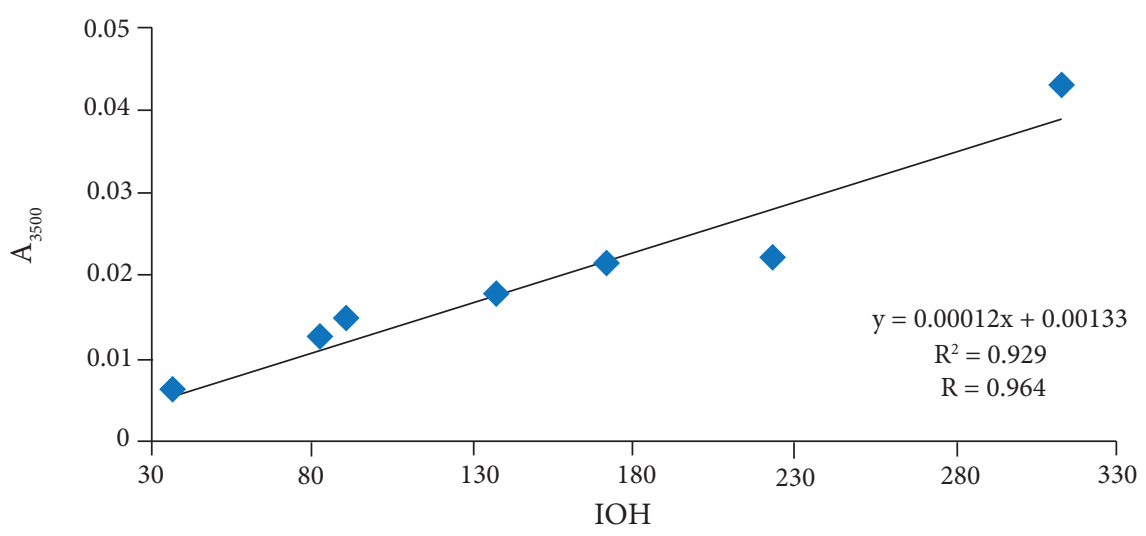

Figure 10. FT-MIR/UATR calibration curve for polyesters - $A_{3500}$ versus $I O H$ (measured by wet chemistry method, supplier's data).

compared to the FT-IR spectrophotometer's accuracy limit ( $\leq 2 \%)$ (Hórak and Vítek 1978) and it fits, since another error was found around $5 \%$ by Chalasani et al. (2013). The last one used the polyol sample derivatization with silane and IOH determined by MIR by reflection and applying a different accessory, the attenuated total reflection (ATR). The band used was $\boldsymbol{\delta} \mathrm{SiCH}_{3}$ at $1250 \mathrm{~cm}^{-1}$ (Smith 1979) and its area was measured. The conditions used in the current FT-MIR methodology (UATR) took less analysis time (1 hour) and presented lower error values, since it did not use derivatization and measurement of any area.

The curve shown in Fig. $11(\mathrm{R}=0.963)$ represents the measured ratio and supplied IOH values, by FT-IR and wet chemistry method, of the polyesters studied. The data measured by FT-IR show good linearity, relative to reference data (from supplier).

\section{IOH determination in polyesters by FT-NIRA}

Figure 12 shows the FT-NIRA spectra of polyester samples used for IOH determination. The band chosen was found at $7000 \mathrm{~cm}^{-1}$, assigned to the first overtone $\mathrm{v} \mathrm{OH}$ at $3500 \mathrm{~cm}-1$. It is possible to observe that this band presents low intensity for $\mathrm{IOH}$ samples between $37-82 \mathrm{mg} \mathrm{KOH} / \mathrm{g}$ (Figs. 12A and B), suggesting a detection limit in this range. Thus, the methodology was applied for $\mathrm{IOH}$ samples between 90 and $313 \mathrm{mg} \mathrm{KOH} / \mathrm{g}$. For these samples, an increase was observed in the $\mathrm{OH}$ band intensity around $7000 \mathrm{~cm}^{-1}$, according to the IOH increase, obeying the Lambert-Beer's law (Smith 1979). 


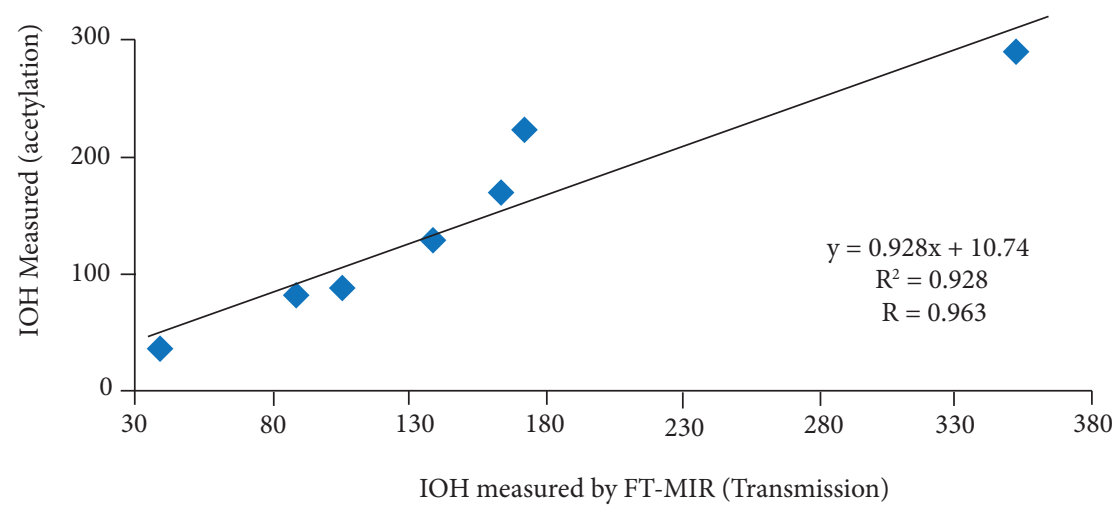

Figure 11. $\mathrm{IOH}$ values (measured by FT-MIR) versus $\mathrm{IOH}$ measured by wet chemistry method (acetylation) for the polyesters studied.

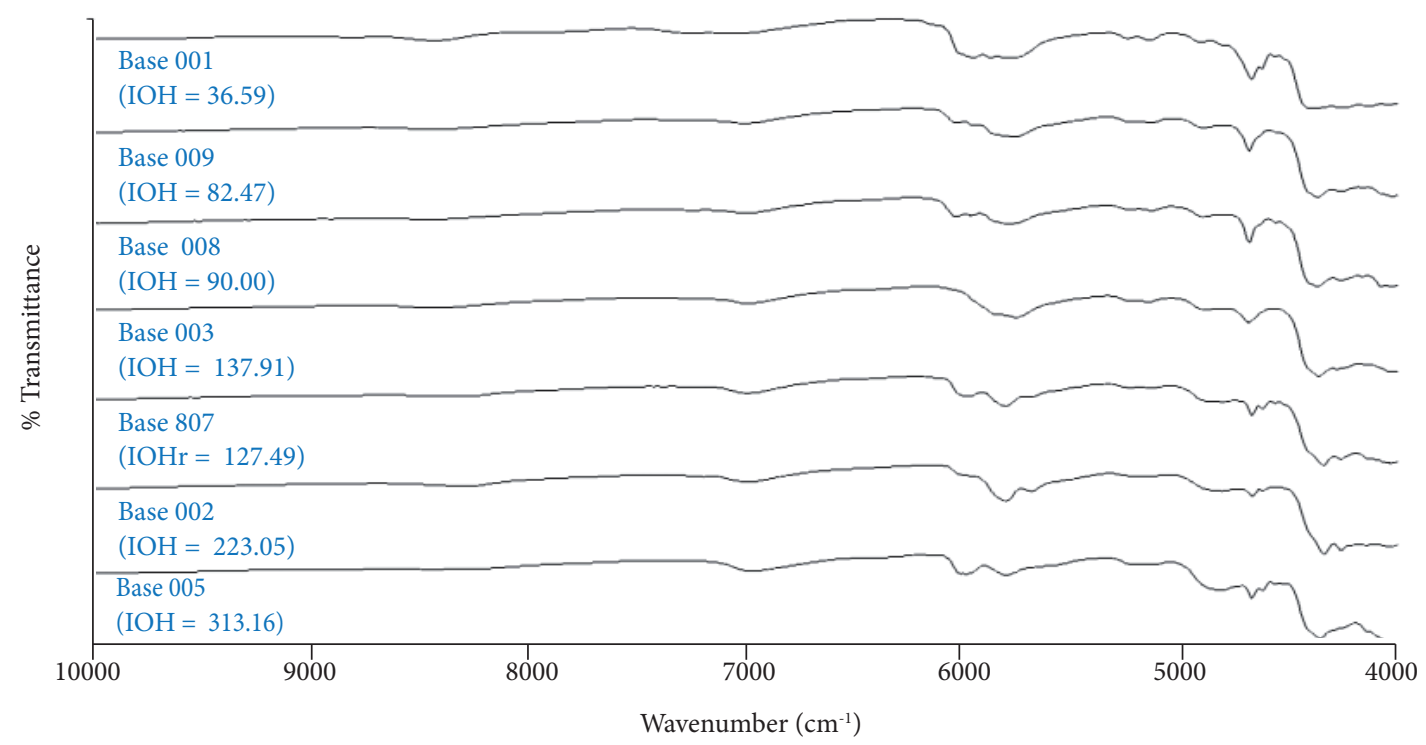

Figure 12. FT-IR/NIRA spectra of polyesters $(\mathrm{IOH}$ in $\mathrm{mg} \mathrm{KOH} / \mathrm{g})$, analyzed as received.

Table 6 includes data related to the developed FT-NIRA methodology. In Fig. 13, the $\mathrm{A}_{7000}$ values are plotted against the relative IOH from the supplier's polyester samples, measured by acetylation (Table 6). Good linear correlation was observed, $R=0.949$, for calibration curve (Eq. 9), with about $90 \%$ of the values explained by the methodology $\left(\mathrm{R}^{2}=0.90103\right)$ :

$$
y=0.00007 x+0.03352
$$

where $y$ is the median value of $\mathrm{A}_{7000}$ and $x$ is the $\mathrm{IOH}$ value $(\mathrm{mg} \mathrm{KOH} / \mathrm{g})$.

In Table 6, it was observed that FT-NIRA methodology error was around 3\%, which is acceptable compared to the FT-IR spectrophotometer's accuracy limit $(\leq 2 \%)$ that is found under ideal conditions of thickness control (Hórak and Vítek 1978). 
Table 6. Methodology data and FT-NIRA for IOH determination in polyesters.

\begin{tabular}{|c|c|c|c|c|c|}
\hline \multirow{3}{*}{ Sample } & \multicolumn{3}{|c|}{ FT-NIRA } & \multirow{2}{*}{\multicolumn{2}{|c|}{$\begin{array}{l}\text { IOH [from supplier wet chemistry } \\
\text { method, acetylation] [mg KOH/g] }\end{array}$}} \\
\hline & \multirow{2}{*}{$\begin{array}{c}\mathrm{A}_{7000} \\
\text { [median value) }\end{array}$} & \multirow{2}{*}{$\begin{array}{l}\text { Standard mean error } \\
\qquad\left[\hat{\sigma}_{\mathrm{m}}\right]\end{array}$} & \multirow{2}{*}{$\begin{array}{l}\text { Relative error } \\
\text { [\%] }\end{array}$} & & \\
\hline & & & & Range & Value measured \\
\hline BASE 008 & 0.037 & 0.001 & 2.7 & $85-90$ & 90 \\
\hline BASE 003 & 0.044 & 0.001 & 2.3 & $128-140$ & 137.91 \\
\hline BASE 807 & 0.047 & 0.002 & 4.2 & $160-180$ & 172.49 \\
\hline BASE 002 & 0.049 & 0.001 & 2.04 & $215-225$ & 223.05 \\
\hline BASE 005 & 0.053 & 0.002 & 3.77 & $300-330$ & 313.16 \\
\hline Methodology error & & 2.7 & & - & - \\
\hline
\end{tabular}

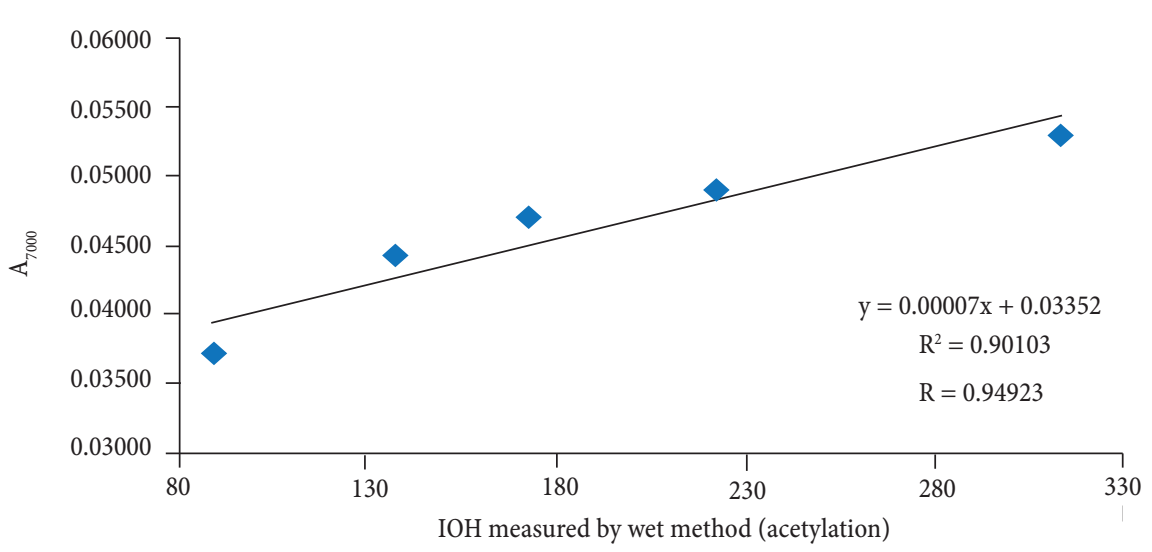

Figure 13. FT-IR/NIRA calibration curve of $A_{7000}$ versus $\mathrm{IOH}$ in $\mathrm{mg} \mathrm{KOH/g}$ (measured by wet chemistry method, supplier's data).

\section{CONCLUSIONS}

FT-IR methodologies for IOH determination were developed in MIR and NIR regions in surfactants (IOH range 46-104 mg $\mathrm{KOH} / \mathrm{g}$ ) and polyesters ( $\mathrm{IOH}$ range $37-310 \mathrm{mg} \mathrm{KOH} / \mathrm{g}$ ), without derivatization. The FT-IR methodology showed good linearity with $\mathrm{IOH}$ values, and it has shown lower variation on the values measured than the ones observed with the wet chemistry method. It has also proved to be faster.

The FT-MIR/transmission/solution methodology was the most suitable for IOH determination in surfactants. On the other hand, the FT-MIR/UATR methodology was the most suitable for polyesters. Between 88 and $98 \%$ of the values found were explained by all MIR and NIRA methodologies developed in this study for surfactants and polyesters. This quantity can be accepted both by the technological aspect, in relation to the specification range, and by the scientific one, that evaluates the precision. This shows the value of the developed methodologies in the application of quality control of the studied surfactants and polyesters.

\section{AUTHORS' CONTRIBUTION}

Conceptualization, Jesus, LL and Dutra RCL; Methodology, Jesus, LL and Dutra RCL; Investigation, Jesus, LL and Diniz MF; Writing - Original Draft, Jesus, LL; Writing - Review and Editing, Jesus, LL, Murakami LMS, Silva, LM, Mattos EC and Dutra RCL; Funding Acquisition, Dutra RCL; Resources, Diniz MF and Mello, TSD; Supervision, Dutra RCL and Diniz MF. 


\section{FUNDERS}

Coordenação de Aperfeiçoamento de Pessoal de Nível Superior [https://doi.org/10.13039/501100002322]

\section{REFERENCES}

Alisson E. Estudo viabiliza uso de nanotubos de carbono em estruturas aeroespaciais. 2017. São Paulo: Agência FAPESP; [accessed 2017 Fev 20]. http://agencia.fapesp.br/estudo_viabiliza_uso_de_nanotubos_de_carbono_em_estruturas_aeroespaciais/24799/

American Society for Testing and Materials (ASTM) E222-17, Subcommittee D16.15 (2017) Standard Test Methods for Hydroxyl Groups Using Acetic Anhydride Acetylation. In: ASTM International. Annual Book of ASTM Standards. Philadelphia: ASTM International. https:// doi.org/10.1520/e0222-17

Baccan N, Andrade JC, Godinho OES, Barone JS (2001) Química analítica quantitativa elementar. São Paulo: Edgard Blucher.

Basf, 2007. Internal Method Supplier Number PM/00007/07.

Botelho EC, Edwards ER, Bittmann B, Burkhart T (2011) Dispersing carbon nanotubes in phenolic resin using an aqueous solution. J Braz Chem Soc 22(11):2040-2047. https://doi.org/10.1590/S0103-50532011001100004

Campos EA, Fernandes MTC, Kawachi EY, Oliveira JIS, Dutra RCL (2015a) Chemical and textural characterization of iron oxide nanoparticles and their effect on the thermal decomposition of ammonium perchlorate. Propell Explos Pyrot 40(6):860-866. https://doi.org/10.1002/ prep. 201500115

Campos EA, Pinto DVBS, Oliveira JIS, Mattos EC, Dutra RCL (2015b) Synthesis, Characterization and Applications of Iron Oxide Nanoparticles. J Aerosp Technol Manag 7(3):267-276. https://doi.org/10.5028/jatm.v7i3.471

Chalasani SRK, Dewasthale S, Hablot E, Shi X, Graiver D, Narayan R (2013) A spectroscopic method for hydroxyl value determination of polyols. J Am Oil Chem Soc 90(12):1787-1793. https://doi.org/10.1007/s11746-013-2334-9

Daltin, D (2011) Tensoativos química, propriedades e aplicações. São Paulo: Blucker.

Damazio D, Dutra RCL, Diniz MF, Mattos EC (2014) Determinação por FT-IR de transmissão e reflexão (UATR) de etileno e propileno em EPDM. Polímeros 24(6):703-710. https://doi.org/10.1590/0104-1428.1536

Damazio D, Santos RP, Diniz MF, Mattos EC, Dutra RCL (2015) Determinação do teor de ENB em EPDM (elastômero puro) por FT-IR de transmissão, por meio de banda relativa. Polímeros 25(2):181-185. https://doi.org/10.1590/0104-1428.1777

Dholakiya B (2012) Unsaturated Polyester Resin for Specialty Applications. Polyester. https://doi.org/10.5772/48479

Dutra RCL (1997) Modificação de Fibra PP com EVA Funcionalizado (PhD thesis). Rio de Janeiro: Universidade Federal do Rio de Janeiro. In portuguese.

Dutra RCL, Soares BG (1998) Determination of the vinyl mercaptoacetate content in poly(ethylene-co-vinyl acetate-co-vinyl mercaptoacetate) (EVASH) by TGA analysis and FTIR spectroscopy. Polymer Bulletin 41(1):61-67. https://doi.org/10.1007/s002890050333

Hórak VM, Vítek A (1978) Interpretation and processing of vibrational spectra. New York: John Wiley \& Sons.

Kazuaki W, Kuwabara H, Furusho N, Tatebe C, Sato K, Akiyama H (2014) A Comparative Study of the Hydroxyl and Saponification Values of Polysorbate 60 in International Food Additive Specifications. Am J Analyt Chem 5(6):199-204. https://doi.org/10.4236/ ajac. 2014.53024

Mello TSD (2017) Quantificação por FT-IR de plastificantes em misturas binárias com nitrocelulose (Dissertation). São José dos Campos: Instituto Tecnológico de Aeronáutica. In portuguese.

Mello TSD, Diniz MF, Dutra RCL (2018) UATR and NIRA evaluation in the quantification of ATBC in NC blends. Polímeros 28(3):239-245. https://doi.org/10.1590/0104-1428.16816

Pant CS, Patil RS (2016) An improved analytical method for determination of hydroxyl number of hydroxyl terminated polybutadiene (HTPB), 1,4-butanediol (nBD) and trimethylol propane (TMP). ACAlJ 16(12):532-534.

Pedreira SM, Pinto JRA, Campos EA, Mattos EC, Junior MSO, Oliveira JIS, Dutra RCL (2016) Methodologies for Characterization of Aerospace Polymers/Energetic Materials - a Short Review. J Aerosp Technol Manag 8(1):18-25. https://doi.org/10.5028/jatm. $\underline{\mathrm{vi1}} .576$

Pimentel MF, Neto BB (1996) Calibração: uma revisão para químicos analíticos. Química Nova 19(3):268-277. 
Rodrigues VC, Dutra RCL, Diniz MF, Mattos EC (2014) Quantificação por NIR/MIR de resina poliuretânica em misturas binárias com nitrocelulose utilizadas em tintas. Polímeros 24(3):367-372. https://doi.org/10.4322/polimeros.2014.027

Rossi CGFT, Dantas TNC, Neto AAD, Maciel MAM (2006) Tensoativos: Uma Abordagem Básica e Perspectivas Para Aplicabilidade Industrial. Rev Univ Rural Ser Cienc Exatas Terra 25(1-2):59-71.

Rossi CGFT, Dantas TNC, Neto AAD, Maciel MAM (2007) Microemulsões: uma abordagem básica e perspectivas para aplicabilidade industrial. Rev Univ Rural Ser Cienc Exatas Terra 26(1-2): 45-66.

Roy RB, Kradjel C (1988) Application of NIRA techniques for the determination of polymer end and functional groups. J Polym Sci A Polym Chem 26(7):1733-1742. https://doi.org/10.1002/pola.1988.080260705

Shen L, Guo A, Xiaoyang Z (2011) Tween surfactants: Adsorption, self-organization, and protein resistance. Surf Sci 605(5-6):494-499. https://doi.org/10.1016/i.susc.2010.12.005

Silva IR, Barreto PLM, Bellettini IC (2013) Estudo das Dispersões Aquosas de Nanotubos de Carbono Utilizando Diferentes Surfactantes. Quim Nova 36(1):5-9. https://doi.org/10.1590/S0100-40422013000100002

Siqueira SHS, Dutra RCL, Diniz MF (2008) Determinação por espectroscopia nas regiões MIR/NIR do teor de NCO em adesivos poliuretânicos. Polímeros 18(1):57-62. https://doi.org/10.1590/s0104-14282008000100012

Smith AL (1979) Applied infrared spectroscopy. New York: John Wiley Sons.

Stark E, Luchter K, Margoshes M (1986) Near-Infrared Analysis (NIRA): A Technology for Quantitative and Qualitative Analysis. Applied Spectroscopy Reviews 22(4):335-399. https://doi.org/10.1080/05704928608060440

Takahashi MFK, Dutra RCL, Diniz MF, Polito WL (1996) Determinação de índices de hidroxila em polibutadienos hidroxilados e de grupos NCO em diisocianatos e pré-polimeros por espectroscopia no infravermelho com transformada de Fourier. Polímeros 6(4):45-52.

Tavassoli-Kafrani MH, Curtis JM, Van de Voort FR (2014) A primary method for the determination of hydroxyl value of polyols by Fourier transform Mid-infrared spectroscopy. J Am Oil Chem Soc 91(6):925:933. https://doi.org/10.1007/s11746-014-2451-0

Vaisman L, Wagner HD, Marom G (2006) The role of surfactants in dispersion of carbon nanotubes. Adv Colloid Interface Sci 128-130:3746. https://doi.org/10.1016/j.cis.2006.11.007

Vargas LR, Poli AKS, Dutra RCL, Souza CB, Baldan MR, Gonçalves ES (2017) Formation of composite polyaniline and graphene oxide by physical mixture method. J Aerosp Technol Manag. 9(1):29-38. https://doi.org/10.5028/jatm.v9i1.697

Walling PL, Dabney JM (1986) Application of near infrared reflectance spectroscopy to the quality assurance of surfactants. J Soc Cosmet Chem 37(6):445-459. 